\title{
Sphingolipids are required for exocyst polarity and exocytic secretion in Saccharomyces cerevisiae
}

\author{
Qingguo Guo ${ }^{1,2}$, Tianrui Zhang², Na Meng², Yuran Duan², Yuan Meng², Dong Sun ${ }^{2}$, Ying Liu²* \\ and Guangzuo Luo ${ }^{1 *}$
}

\begin{abstract}
Background: Exocytosis is a process by which vesicles are transported to and fused with specific areas of the plasma membrane. Although several studies have shown that sphingolipids are the main components of exocytic compartments, whether they control exocytosis process is unclear.

Results: Here, we have investigated the role of sphingolipids in exocytosis by reducing the activity of the serine palmitoyl-transferase (SPT), which catalyzes the first step in sphingolipid synthesis in endoplasmic reticulum. We found that the exocyst polarity and exocytic secretion were impaired in /cb1-100 mutant cells and in wild type cells treated with myriocin, a chemical which can specifically inhibit SPT enzyme activity, suggesting that sphingolipids controls exocytic secretion. This speculation was further confirmed by immuno-fluorescence and electron microscopy results that small secretory vesicles were accumulated in /cb1-100 mutant cells.
\end{abstract}

Conclusions: Taken together, our results suggest that sphingolipids are required for exocytosis. Mammals may use similar regulatory mechanisms because components of the exocytic secretion apparatus and signaling pathways are conserved.

Keywords: Sphingolipid, Ceramide, Serine palmitoyl-transferase, Exocyst, Exocytosis

\section{Background}

Exocytosis is a cellular process of secretory vesicles transporting to specific areas of the plasma membrane [18]. Cell surface growth is ultimately performed through exocytic secretion, in which post-Golgi secretory vesicles carrying proteins and lipids are docked to and then fused with the plasma membrane [15]. The exocyst complex is composed of Sec3, Sec5, Sec6, Sec8, Sec10, Sec15, Exo70, and Exo84, which "tethers" the secretory vesicles and the plasma membrane before SNARE-mediated membrane

\footnotetext{
*Correspondence: liuying@cmu.edu.cn; gzluo@cmu.edu.cn

1 Institute of Translational Medicine, China Medical University,

Shenyang 110122, China

${ }^{2}$ Department of Biochemistry and Molecular Biology, China Medical

University, Shenyang 110122, China
}

fusion $[12,15,18,33,44]$. Previous studies have shown that polarity of most exocyst subunits in bud depends on exocytic secretion $[1,24,26,45]$.

Sphingolipid biosynthesis in yeast begins in the endoplasmic reticulum (ER) and is completed in the Golgi apparatus [6,36]. Analysis of the lipid class composition indicates post-Golgi exocytic vesicles and the trans-Golgi network (TGN) contain large amount of sphingolipids, including ceramide, inositolphosphoryl ceramide (IPC), mannosyl-inositolphosphoryl ceramide (MIPC), and mannosyl-diinositolphosphoryl ceramide $\left(\mathrm{M}(\mathrm{IP})_{2} \mathrm{C}\right)[20$, 43], suggesting sphingolipids may be involved in exocytic secretion. The mutants of several synthesis enzymes in the sphingolipids pathway have been found to impair the transport of the artificial fusion protein Fus-MidGFP from Golgi to plasma membrane, supporting this 
speculation. The elongase Elo3 which synthesizes very long chain 20-26-carbon fatty acids from C18-CoA primers, the sphinganine C4-hydroxylase Sur2 which catalyses the conversion of sphinganine to phytosphingosine, and the alkaline ceramidase Ypc1 which catalyzes both breakdown and synthesis of phytoceramide, are required for a cargo protein after synthesis at the ER throughout the secretory pathway to the cell surface [37]. Notably, it was reported that cell surface delivery of Fus-Mid-GFP is blocked in $l c b 1-100$ mutant, in which the activity of serine palmitoyl-transferase, an enzyme in the first step of sphingolipids synthesis, is dramatically reduced at a restrictive temperature [37]. These facts suggest that sphingolipids may be involved in exocytic secretion. However, there is no direct evidence to confirm this speculation yet.

In this study, we have investigated the role of sphingolipids in exocytosis process in the budding yeast Saccharomyces cerevisiae. We found that polarized localization of exocyst complex at the bud and the exocytic secretion of Bgl2 and invertase rely on the activity of serine palmitoyl transferase, the initial enzyme in sphingolipid synthesis, but not the enzymes required for ceramides. We also found that small secretory vesicles were accumulated in lcb1-100 mutant cells, suggesting the exocytic secretion was impaired. These results suggest that sphingolipids are required for exocytic secretion.

\section{Results}

\section{Activity of serine palmitoyl-transferase is required for polarized localization of exocyst}

To explore the role of sphingolipids in exocytosis, we used the temperature sensitive mutant strain $l c b 1-100$. The $L C B 1$ gene encodes a subunit of the serine palmitoyltransferase, which catalyzes the first step in sphingolipid synthesis [2, 7]. $l c b 1-100$ mutant is therefore unable to produce sphingoid bases, ceramides, and sphingolipids at restrictive temperature $[17,27,30,46]$. Since the delivery of exocyst subunits to polarized growth sites relies on exocytic secretion pathway, we want to know whether sphingolipids are required for polarized localization of exocyst. To test this hypothesis, the exocyst subunits, Sec3, Sec5, Sec8, and Exo70, were GFP tagged at the C-terminal of each protein on the chromosome of wild type and $l c b 1-100$ mutant strains, respectively. The GFP tagged exocyst subunit yeast strains were grown to early $\log$ phase at $25^{\circ} \mathrm{C}$, and then half of the cells were shift to $39^{\circ} \mathrm{C}$ for $60 \mathrm{~min}$. The collected cells were fixed and examined under a fluorescence microscope. As shown in Fig. 1a, b, Sec3-GFP, Sec5-GFP, Sec8-GFP, and Exo70-GFP were located in buds at both $25^{\circ} \mathrm{C}$ and $39^{\circ} \mathrm{C}$ in more than $80 \%$ of wild-type cells. Similarly, the GFP tagged exocyst subunits were located in buds at $25{ }^{\circ} \mathrm{C}$ in more than $70 \%$ of $l c b 1-100$ mutant cells. At $39{ }^{\circ} \mathrm{C}$, however, Sec3-GFP, Sec5-GFP, Sec8-GFP, and Exo70-GFP were located in buds of less than $15 \%$ of $l c b 1-100$ mutant cells. The amount of the GFP tagged exocyst subunits did not differ significantly between wild type and lcb1-100 mutant cells after shifting to $39{ }^{\circ} \mathrm{C}$ for $60 \mathrm{~min}$ (Additional file 1: Figure S1A). To exclude the possibility that the $l c b 1-100$ mutants cells are dead or dying under our experimental condition, the viability of wild type and $l c b 1-100$ mutants cells shifted from 25 to $39^{\circ} \mathrm{C}$ for 60 min were measured. As shown in Additional file 1: figure S2, around $80 \%$ of the $l c b 1-100$ mutant cells were still viable after incubated at $39^{\circ} \mathrm{C}$ for $60 \mathrm{~min}$, suggesting that the mis-localization of exocyst components in lcb1-100 mutant cells was not because of cell death. Consistent with previous reports, treatment at restrictive temperature for 60 min did not arrest $l c b 1-100$ mutant cells at early G1 phase of the cell-cycle progression [46], suggesting the polarized growth of $l c b 1-100$ mutant cells was not completely inhibited in such a short term. Because the bud is considered to be the growth area of budding yeast, this result indicates that sphingolipids are required for polarized localization of exocyst at the growth sites.

To confirm the role of sphingolipids in exocytosis, we inhibited the activity of SPT enzyme by treating wild type cells with myriocin to determine if exocyst is depolarized. It has been shown that myriocin specifically inhibits the activity of serine palmitoyl transferase, and has been widely used to reduce sphingolipid level in eukaryotic cells [5, 22, 27], Daquinag et al. 2012. As shown in Fig. 1c, d, myriocin did trigger a loss of exocyst in buds after cells were treated with $10 \mu \mathrm{g} / \mathrm{ml}$ myriocin for $1 \mathrm{~h}$. The localization of Sec3-GFP, Sec5-GFP, Sec8-GFP, and Exo70-GFP was polarized in more than $72 \%$ of wild type cells without myriocin treatment. However, after treated with myriocin for $1 \mathrm{~h}$, the polarized localization of these exocyst subunits was maintained only in less than $23 \%$ of the cells. The amount of the GFP tagged exocyst subunits did not differ significantly between myriocin treated and untreated cells (Additional file 1: Figure S1B). To exclude the possibility that the cells treated with myriocin are dead under our experimental condition, the viability of wild type cells treated with myriocin for $1 \mathrm{~h}$ were measured. As shown in Additional file 1: Figure S3, more than $90 \%$ of the cells treated with myriocin were still viable, suggesting that the mislocalization of exocyst components in myriocin treated cells was not because of cell death. It was reported that sphingolipids are required for polarized localization of actin patch [46]. To confirm the effect of myriocin on wild type cells, we measured actin organization in cells 


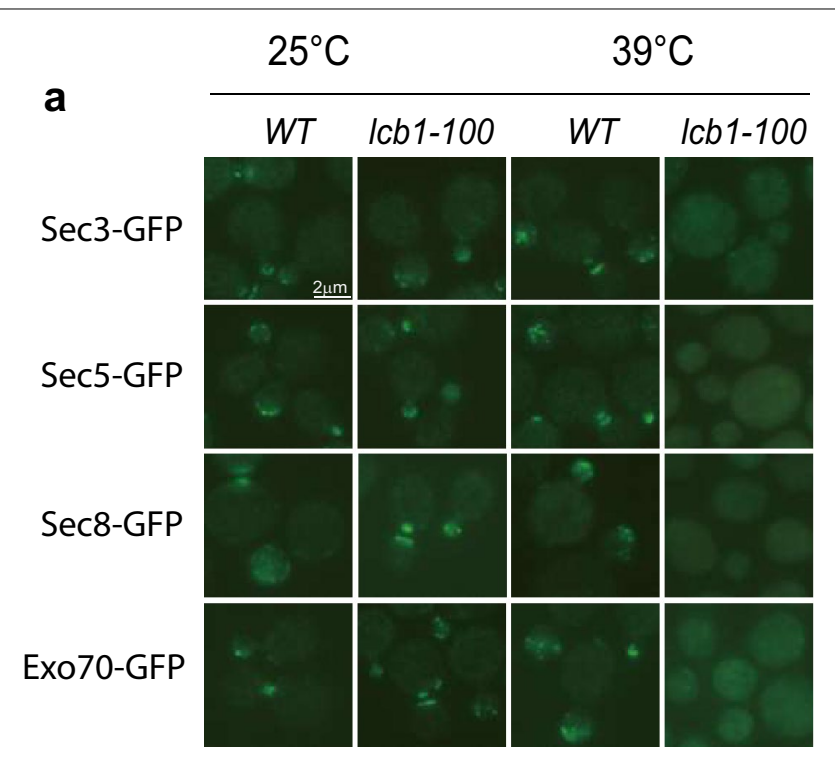

b

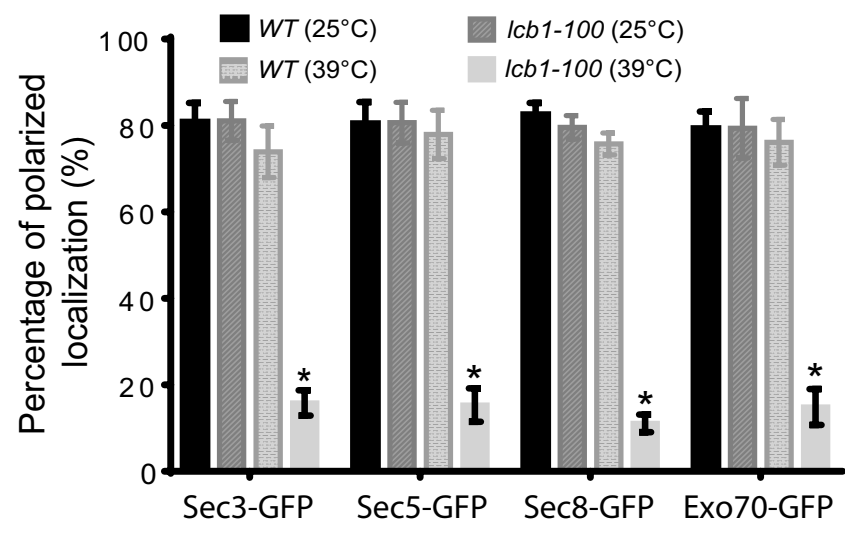

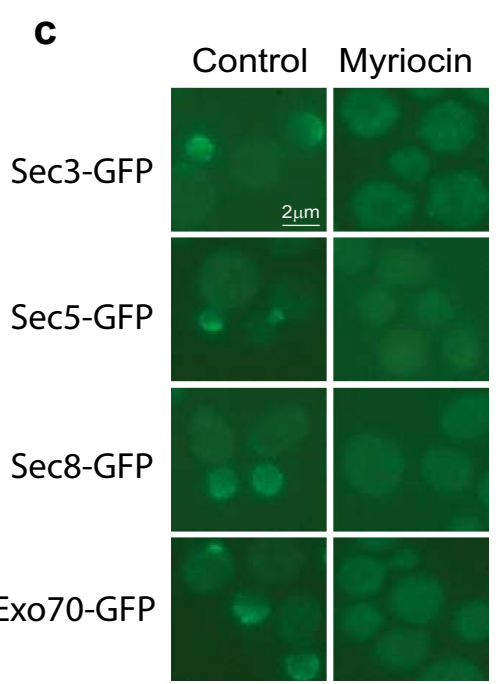

d

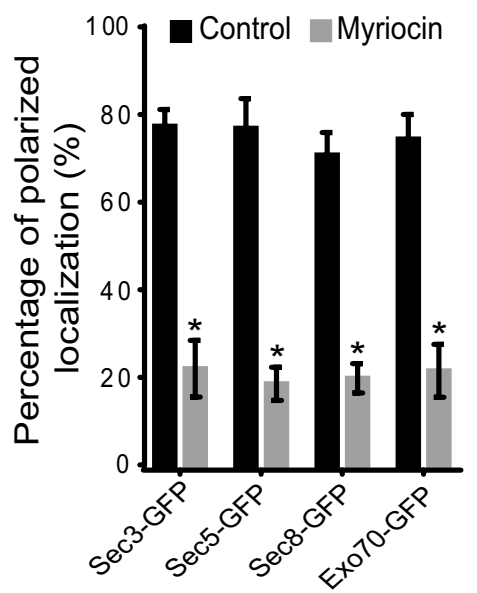

Fig. 1 Localization of the exocyst components in Icb1-100 mutant cells and in cells treated with myriocin. a The yeast strains harboring SEC3-GFP, SEC5-GFP, SEC8-GFP or EXO70-GFP on the chromosome were grown to early log phase in YPD liquid medium overnight at $25^{\circ} \mathrm{C}$. The cells were then shifted from 25 to $39^{\circ} \mathrm{C}$ for 60 min before fluorescence microscopy. GFP-tagged Sec3, Sec5, Sec8 and Exo70 remained polarized in buds of wild-type cells at both $25^{\circ} \mathrm{C}$ and $39^{\circ} \mathrm{C}$. The exocyst components in Icb1-100 mutant cells were located to bud at $25^{\circ} \mathrm{C}$ but dispersed in cytoplasm at $39^{\circ} \mathrm{C}$ after the temperature shift. Scale bar, $2 \mu \mathrm{m}$. b Statistical analysis was performed on the percentage of polarized localization in each yeast strains at $25^{\circ} \mathrm{C}$ and $39^{\circ} \mathrm{C}$ in $\mathbf{a} . \mathrm{n}=3$. Three independent experiments were performed. ${ }^{*} \mathrm{p}<0.01$. c Wild-type cells harboring SEC3-GFP, SEC5-GFP, SEC8-GFP or EXO70-GFP on the chromosome were grown to early log phase in YPD liquid medium overnight at $25^{\circ} \mathrm{C}$. The cells were then treated with or without $10 \mu \mathrm{g} / \mathrm{ml}$ myriocin for $60 \mathrm{~min} .2 \mu \mathrm{l}$ of the suspension was dropped onto the microslide for microscopy. Scale bar, $2 \mu \mathrm{m}$. $\mathbf{d}$ Statistical analysis was performed for the percentage of polarized exocyst localization in each yeast strains $\mathbf{a} . \mathrm{n}=3$. Three independent experiments were performed. ${ }^{*} p<0.01$

treated with $10 \mu \mathrm{g} / \mathrm{ml}$ myriocin for $1 \mathrm{~h}$. Consistent with the previous report, the polarity of actin organization was disrupted upon myriocin treatment under our experimental condition (data not shown), suggesting the sphingolipid level was reduced in these cells.
Taken together, these results confirm the critical role of sphingolipids in controlling polarized localization of exocyst complex. 


\section{Activity of serine palmitoyl-transferase is required for exocytic secretion}

To determine whether sphingolipids control exocytic secretion, we have analyzed the secretion of two cargoes in wild type and $l c b 1-100$ mutant cells, the cell wall endoglucanase $\mathrm{Bgl} 2$ and the periplasmic enzyme invertase, which are well-characterized markers for the two major classes of post-Golgi vesicles that deliver proteins to the cell surface $[8,16,17,23,25,26,48]$. As shown in Fig. 2a, b, the internal Bgl2 level in wild type cells is barely detected at both $25^{\circ} \mathrm{C}$ and $39{ }^{\circ} \mathrm{C}$. The internal $\mathrm{Bgl} 2$ in lcb1-100 mutant cells at $25^{\circ} \mathrm{C}$, however, is significantly higher than that in wild type cells, and the secretion defect of Bgl2 in $l c b 1-100$ was exaggerated at $39^{\circ} \mathrm{C} \mathrm{com-}$ pared to wild type cells. Invertase represents a smaller branch of cargoes in the secretory pathway and is also used as an exocytic secretion marker as a complement to the Bgl2 secretion assay $[8,23,26,35,48]$. As shown in a

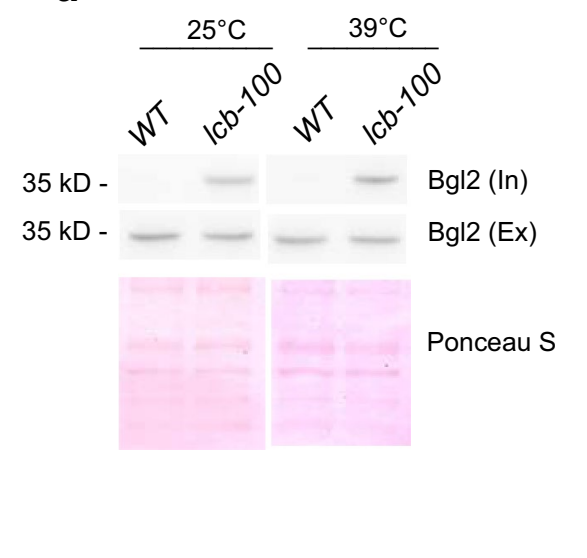

d

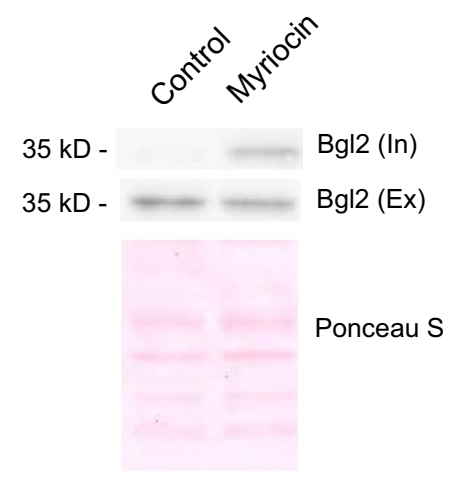

b

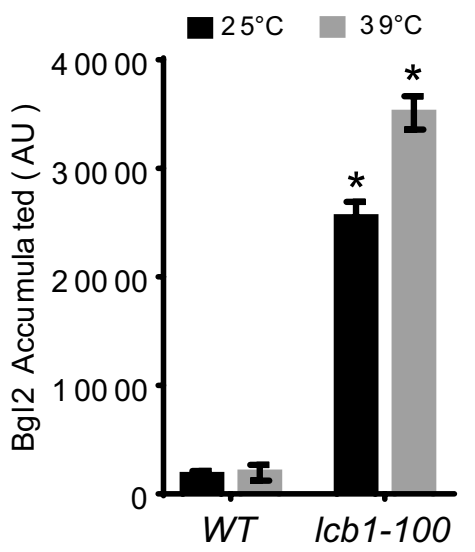

e

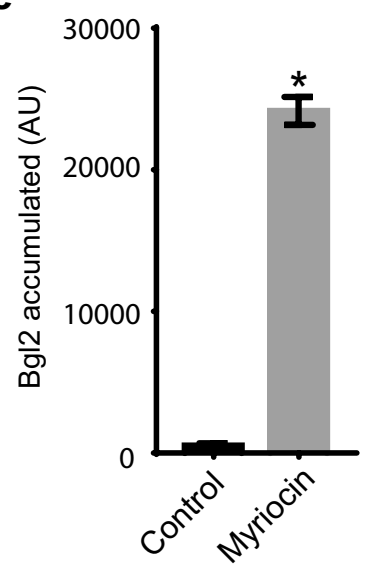

C

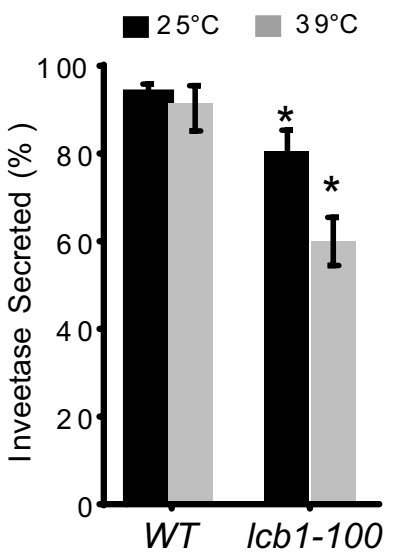

f

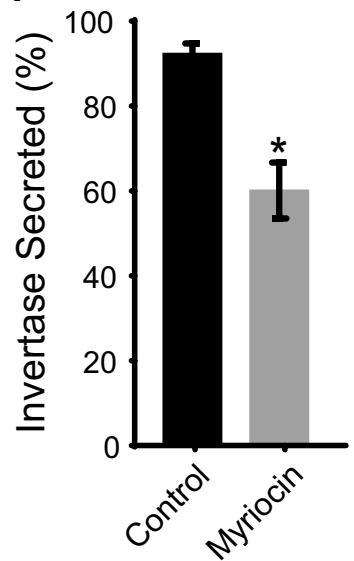

Fig. 2 Sphingolipids are required for exocytic secretion. a Bgl2 secretion in the wild-type and /cb1-100 temperature-sensitive mutant. Wild-type and /cb1-100 mutant cells were grown to early log phase in YPD liquid medium overnight at $25^{\circ} \mathrm{C}$. The cells were then shifted to $25^{\circ} \mathrm{C}$ or $39^{\circ} \mathrm{C}$ for 60 min. Bgl2 secretion was analyzed by western blot using anti-Bgl2 antibody. The total protein on PVDF membranes were stained with Ponceau $\mathrm{S}$ as loading control. $\mathbf{b}$ Quantification of the amounts of Bgl2 accumulation in the wild-type and $/ \mathrm{cb} 1-100 \mathrm{mutant}$ in $\mathbf{a}$. $\mathrm{n}=3$. ${ }^{*} \mathrm{p}<0.01$. $\mathbf{c}$ Invertase secretion in the wild-type and /cb1-100 mutant cells. Wild-type and /cb1-100 mutant were grown to early log phase in YPD liquid medium overnight at $25^{\circ} \mathrm{C}$. The cells were then shifted to $25^{\circ} \mathrm{C}$ or $39^{\circ} \mathrm{C}$ for $60 \mathrm{~min}$. Then the invertase secretion were examined. $\mathbf{d}$ Bgl 2 secretion in wild type cells treated with or without myriocin. Wild-type cells were grown to early log phase in YPD liquid medium overnight at $25^{\circ} \mathrm{C}$. Myriocin was added into the medium to a final concentration of $10 \mu \mathrm{g} / \mathrm{ml}$, and the cells were incubated at $25^{\circ} \mathrm{C}$ for 60 min. External and internal Bgl 2 secretion was analyzed by western blot using anti-Bgl2 antibody. The total protein on PVDF membranes were stained with Ponceau S as loading control. e Quantification of the amounts of Bgl2 accumulation in $\mathbf{a} . \mathrm{n}=3$. Three independent experiments were performed. ${ }^{*} p<0.01$. $\mathbf{f}$ Invertase secretion in wild-type cells treated with or without myriocin. Wild-type yeast were grown to early log phase in YPD liquid medium overnight at $25^{\circ} \mathrm{C}$. Myriocin was added into the medium to a final concentration of $10 \mu \mathrm{g} / \mathrm{ml}$, and the cells were incubated at $25^{\circ} \mathrm{C}$ for $60 \mathrm{~min}$. $\mathrm{n}=3$. Three independent experiments were performed. ${ }^{*} p<0.01$ 
Fig. 2c, the secretion efficiency of invertase in $l c b 1-100$ mutant cells is significantly reduced compared to that in wild type cells at $25^{\circ} \mathrm{C}$. At $39{ }^{\circ} \mathrm{C}$, the secretion defect of invertase in lcb1-100 was exaggerated compared to wild type cells. The secretion defects of $\mathrm{Bgl} 2$ and invertase in lcb1-100 mutant cells indicate that sphingolipids are required for exocytic secretion.

To confirm the role of sphingolipids in regulating exocytic secretion, two type of exocytic cargoes, Bgl2 and invertase, were examined in cells treated with myriocin, which can specifically inhibit activity of SPT enzyme. As shown in Fig. 2d, e, in cells without myriocin treatment, very small amount of Bgl2 was detected in cytosol. However, the amount of Bgl2 retained in the cytosol of cells treated with $10 \mu \mathrm{g} / \mathrm{ml}$ myriocin significantly increased compared to cells without myriocin treatment. The secretion of invertase was also measured in cells treated with myriocin. As shown in Fig. $2 \mathrm{f}$, more than $90 \%$ of the invertase was secreted out of cytosol in cells without treatment. In cells treated with $10 \mu \mathrm{g} / \mathrm{ml}$ myriocin for $1 \mathrm{~h}$, however, less than $60 \%$ of invertase was secreted out of cytosol, which is significantly reduced compared to cells without myriocin treatment. Taken together, we conclude that exocytic secretion was inhibited in cells treated with myriocin.

\section{Polarized localization of Sec4 was impaired in Icb1-100 mutant cells}

We have experimentally demonstrated that sphingolipids are required for polarized localization of exocyst, but its role in vesicle trafficking remains unknown. Sec4, the Rab protein residing on the post-Golgi vesicles, has been widely used as a marker by immuno-fluorescence to examine the subcellular localization of post-Golgi vesicles $[9,26,38,39,41,48]$. We therefore examined the localization of Sec4 in $l c b 1-100$ mutant cells by immunofluorescence. Wild type and $l c b 1-100$ mutant strains were grown to early log phase at $25^{\circ} \mathrm{C}$, then shifted to $39{ }^{\circ} \mathrm{C}$ for $60 \mathrm{~min}$. After antibody incubation for immuno-fluorescence, the cells were observed under the fluorescence microscope. As shown in Fig. 3, Sec4 was polarized in more than $82 \%$ of wild type cells. However, after treated at $39^{\circ} \mathrm{C}$ for $60 \mathrm{~min}$, the polarized localization of Sec 4 was maintained only in less than $15 \%$ of the $l c b 1-100$ mutant cells. This result suggests that either there is no postGolgi vesicles produced or the secretory vesicles are dispersed in $l c b 1-100$ mutant cells.

\section{Secretory vesicles were accumulated in Icb1-100 mutant cells}

The events order of the exocytic secretory pathway in Saccharomyces cerevisiae has been determined using the temperature-sensitive secretory mutants $[1,18,15,34$,

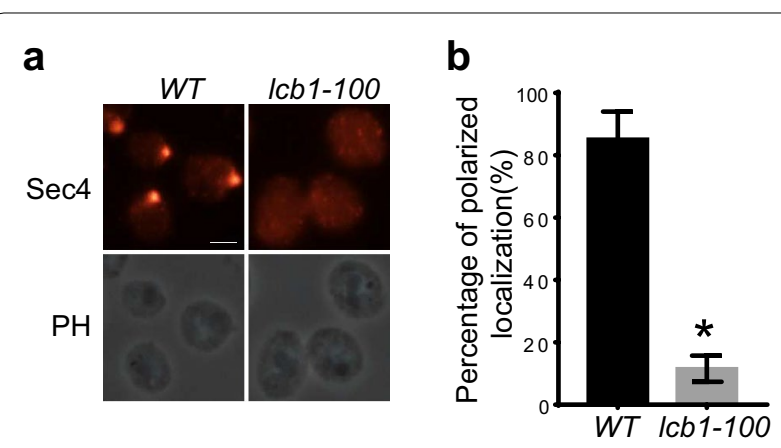

Fig. 3 Localization of Sec4 in wild-type and /cb1-100 mutant cells. a Wild type and /cb1-100 mutant cells were grown to early log phase at $25^{\circ} \mathrm{C}$. The cells were then shifted from 25 to $39^{\circ} \mathrm{C}$ for $60 \mathrm{~min}$ before immuno-fluorescence microscopy. Sec4 is polarized in wild type cells, while it is dispersed in /cb1-100 mutant cells at restrictive temperature. $\mathbf{b}$ Statistical analysis was performed on the percentage of polarized localization of Sec4 in yeast strains in $\mathbf{a}$. $n=3$. Three independent experiments were performed. ${ }^{*} p<0.01$

$35,40,45]$, which confirmed that as a secretory protein matures it usually moves sequentially from the cytosol to endoplasmic reticulum (ER), Golgi, plasma membrane, and finally is exocytosed upon the fusion of post-Golgi vesicles and plasma membrane. Although we have found that sphingolipids are required for $\mathrm{Bgl} 2$ and invertase secretion, it is not clear how sphingolipids affect exocytic vesicle trafficking process. To answer this question, we examined the subcellular structure of wild type and lcb1-100 mutant at restrictive temperature by electron microscopy. As shown in Fig. 4a, b, about 40 vesicles per section are accumulated in $l c b 1-100$ mutant, but less than 3 vesicles per section found in wild type. No elongated ER or Berkeley Body was observed in both wild type and lcb1-100 mutant cells. We further measured the diameter of vesicles accumulated in $l c b 1-100$ mutant cells. As shown in Fig. 4c, d, the average diameter of vesicles in $l c b 1-100$ is around $40 \mathrm{~nm}$ and the size of most vesicles are 31-60 nm, which is very different from the size of post-Golgi secretory vesicles, $80-100 \mathrm{~nm}$. It has been suggested that the small vesicles with size of 40-60 nm may originated from either ER or Golgi complex [34, 35], and may mediate transfer of material from the ER to the Golgi [35]. However, we can not conclude that sphingolipids mediate the step of ER to Golgi during exocytic secretion. Further experiments are needed to confirm this speculation.

\section{Ceramides and complex sphingolipids are not required for exocytosis}

Previous reports indicate exocytic vesicles contain large amount of ceramide and complex sphingolipids including IPC, MIPC, and $\mathrm{M}(\mathrm{IP})_{2} \mathrm{C}[20,43]$, suggesting these 
a
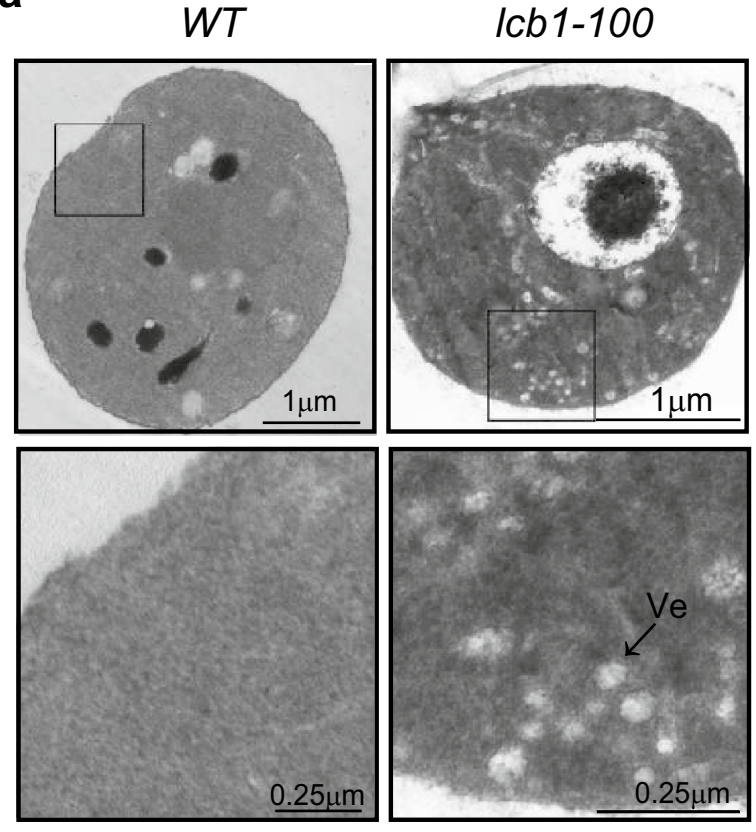

Icb1-100

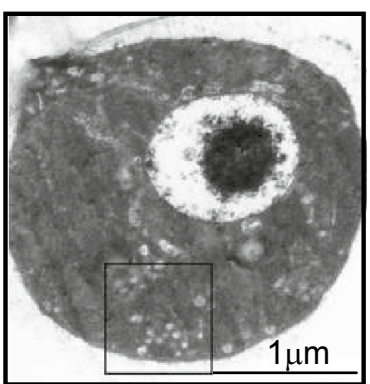

d

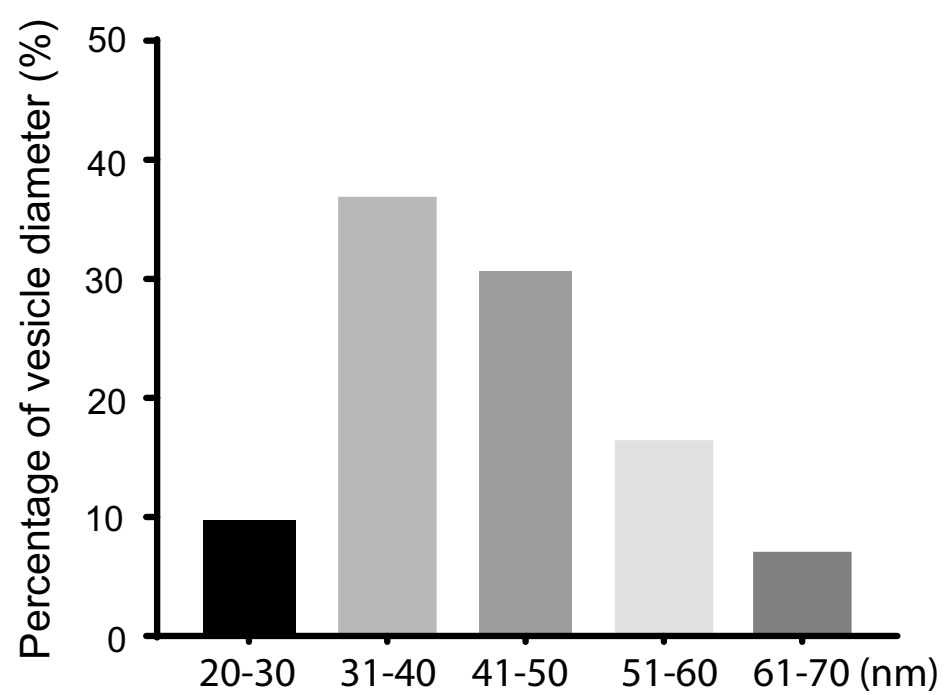

b

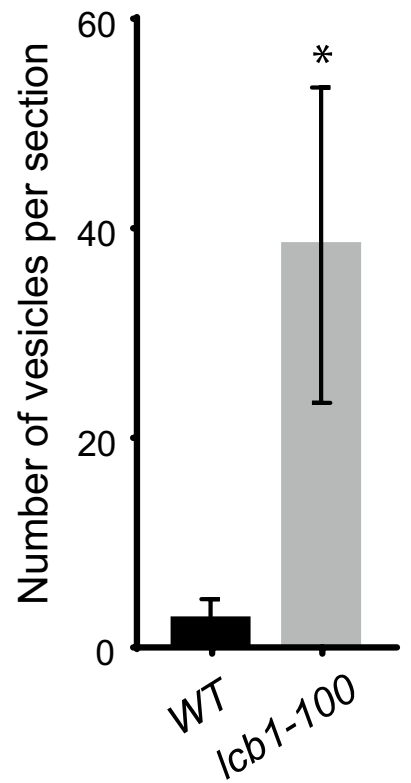

Fig. 4 Secretory vesicles were accumulated in /cb1-100 mutant cells at restrictive temperature. a Wild-type and /cb1-100 mutant cells were grown to early log phase in YPD liquid medium overnight at $25^{\circ} \mathrm{C}$ and then shift to $39^{\circ} \mathrm{C}$ for 60 min. The cells were fixed, stained, and examined by thin-section electron microscopy. b Statistical analysis of vesicle accumulation in wild type and /cb1-100 mutant cells in a. n=15. * $\mathrm{p}<0.01$. "Ve", vesicle. c Diameter measurement of vesicles accumulated in Icb1-100. $\mathrm{n}=600$. $\mathbf{d}$ Histogram of vesicle diameter distribution in the $/ \mathrm{cb} 1-100$ mutant cell shown in $\mathbf{c}$

sphingolipids may mediate exocytic secretion. To test this hypothesis, we examined the exocyst polarity and exocytic secretion in cells in which the synthesis of ceramides and complex sphingolipids were impaired with Fumonisin B1 and Aureobasidin A, respectively. As shown in Fig. 5a, b, both treatments of $500 \mu \mathrm{M}$
C

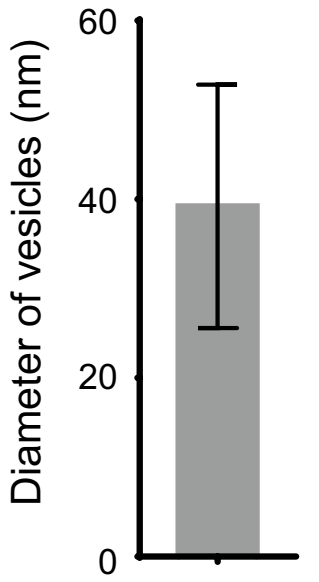

Fumonisin B1 and $10 \mu \mathrm{g} / \mathrm{ml}$ Aureobasidin A did not affect the polarized localization of exocyst subunits of Sec3-GFP, Sec5-GFP, Sec8-GFP, and Exo70-GFP, even the cell growth was significantly inhibited at the same conditions (data not shown). We also measured the secretion of $\mathrm{Bgl} 2$, the cell wall endo-glucanase, in cells treated with 


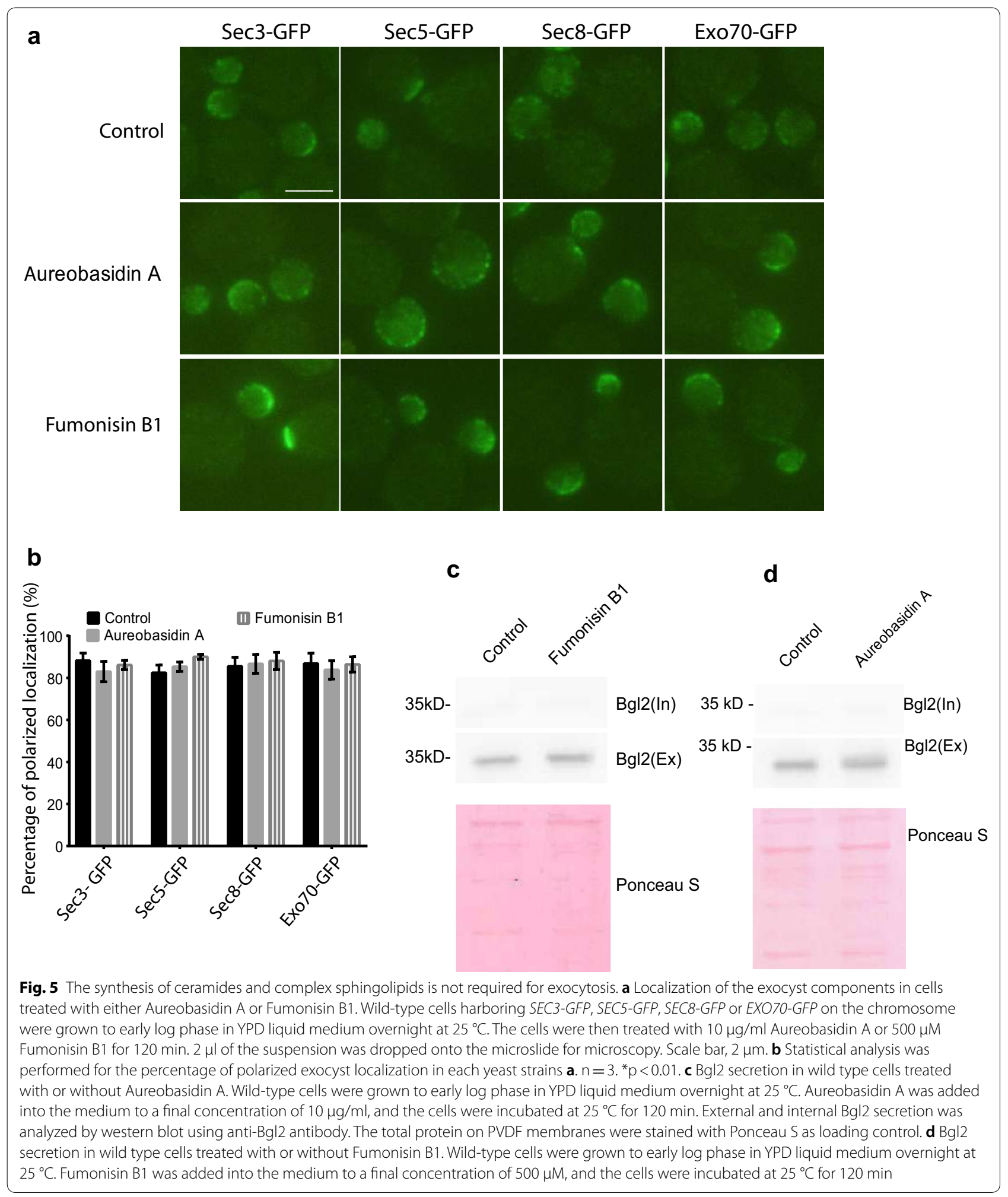

either Fumonisin B1 or Aureobasidin A. As shown in Fig. $5 \mathrm{c}, \mathrm{d}$, similar to cells without treatment, there was no accumulation of internal Bgl2 found in the cytosol in cells treated with either Fumonisin B1 or Aureobasidin A. These results suggest that ceramides and complex sphingolipids are not required for exocytosis. 


\section{Discussion}

Sphingolipids are abundant components of eukaryotic membranes, where they play essential biological roles. Previous data showed that exocytic vesicles and the trans-Golgi network (TGN) contain large amount of sphingolipids, including ceramide, IPC, MIPC, and $\mathrm{M}(\mathrm{IP})_{2} \mathrm{C}$ [20], suggesting that these sphingolipids may mediate exocytosis. Several studies have suggested that sphingolipids may be involved in regulation of exocytosis $[3,17,20,21,31,37]$, but their roles in this critical cellular process is unclear. Although it has been reported that exocytosis is selectively blocked in $l c b 1-100$ cells at restrictive temperature, vesicle accumulation or secretory compartment enlargement had not been detected [17]. Because cells with a block in the secretory pathway usually accumulate secretory vesicles or enlarge secretory compartments such as elongated ER or Berkeley Bodies [35], the result that there was no accumulation of secretory vesicles or enlarged secretory compartments found in $l c b 1-100$ seems unusual and is controversial to the fact that exocytosis is selectively blocked in this mutant [17]. To confirm the requirement of sphingolipids for exocytosis, we treated $l c b 1-100$ mutant at a higher restrictive temperature of $39^{\circ} \mathrm{C}$, which has used to inhibit the Lcb1 enzyme activity in $l c b 1-100$ mutant strain $[4,19]$. Under our experimental conditions, we detected block of exocytic secretion and accumulation of small secretory vesicles (Figs. 2, 4), indicating that sphingolipids are required for exocytosis. This conclusion is confirmed by the results that exocytic secretion was blocked in cells treated with myriocin (Fig. 2). The experimental conditions may contribute to the different electron microscopy results between our study and the previous report.

Although it has been reported that exocytic vesicles contain ceramides and complex sphingolipids including IPC, MIPC, and $\mathrm{M}(\mathrm{IP})_{2} \mathrm{C}[20]$, our results show that the exocyst polarity and exocytic secretion were not affected in cells defective in the synthesis of ceramides and complex sphingolipids (Fig. 5), suggesting that the exocytic secretion does not need the synthesis of ceramide and complex sphingolipids. Instead, our results indicate the delivery of ceramide and complex sphingolipids to plasma membrane relies on exocytosis. It has been suggested that sphingosines are produced in ER, and they have two roles in cells, either as a component in membranes or as transduction signal molecules [6,7]. Because the $l c b 1-100$ mutant is unable to produce sphingoid bases in ER, we speculate that ER-to-Golgi exocytic vesicles contain sphingosines or the fusion of these vesicles with Golgi requires sphingosines. Further experiments are needed to confirm this speculation.

One interesting result found in our study is that sphingolipids regulate the subcellular localization of
Sec3 (Figs. 1, 3). Unlike other exocyst subunits, Sec3 itself exists on the plasma membrane and does not rely on the transport of secretory vesicles to polarized growth sites $[1,13,17,26]$. Currently, the regulators found to be able to control the polarized localization of Sec3 includes Cdk1, Cdc42, and Rho1 [10, 13, 28, $29,49]$. Therefore, the mispolarization of Sec3 in serine palmitoyl-transferase defecting cells may due to the composition change of sphingolipids in the plasma membrane or the activity reduction of Cdk1, Cdc42, and Rho1. Further experiments are required to explore how sphingolipids regulates the polarity of Sec3 at growth sites.

It has been reported that the polarity of the actin organization was disrupted in $l c b 1-100$ cells or in cells treated with myriocin [46]. Because the polarity of most exocyst subunits relies on the transport of postGolgi secretory vesicles along actin cables to polarized growth sites $[1,13,17,26]$, one may argue that the mislocalization of Sec5-GFP, Sec8-GFP, and Exo70-GFP in lcb1-100 cells or in cells treated with myriocin is an indirect effects of actin impairment. However, the electron microscopy results in our study show that the diameter of accumulated small vesicles is around $40 \mathrm{~nm}$, which is very different from the size of post-Golgi secretory vesicles, $80-100 \mathrm{~nm}$, suggesting the mis-localization of Sec5-GFP, Sec8-GFP, and Exo70-GFP in $l c b 1-100$ cells or in cells treated with myriocin is not an outcome of exocytic transport of Golgi apparatus to plasma membrane. Considering the size of small vesicles and the fact that the SPT enzyme is located in ER, we speculate that the impairment of exocytic transport from ER to Golgi apparatus led the mis-localization of Sec5-GFP, Sec8-GFP, and Exo70-GFP.

Although sphingolipids have long been considered as an intermediate in the process of sphingolipid metabolism, it was reported that the level of sphingolipid LCBs increased transiently and activated Pkh1/2 kinases by thermal stimulation [24]. Pkh1/2 are highly homologous to mammalian PDK1, and can activate the downstream AGC protein kinases, such as Ypk1/2 (gamma cell SGK1 homolog), Sch9 (homologous to mammalian cells Akt, PKB, S6K), and Pkc1 (mammalian cell PKC homologous), to regulate several biological processes including proliferation and aging [4-6, 27, 32]. Since sphingolipids are required for exocytic secretion, one would expect that Pkh1/2 and the downstream AGC kinases also involved in exocytosis. However, we found that the exocytic secretion is not affected in the mutants of these kinases (unpublished data), suggesting the sphingolipid LCB-Pkh1/2 pathway did not regulate exocytic secretion process. It seems that sphingolipids regulate exocytic secretion through controlling sphingolipid metabolism, 
but the possibility that sphingolipids regulate exocytosis through other signal pathway is not excluded.

\section{Conclusions}

Our results suggest that sphingolipids are required for exocytosis. Mammals may use similar regulatory mechanisms because components of the exocytic secretion apparatus and signaling pathways are conserved.

\section{Methods}

\section{Yeast strains and plasmids}

Standard methods were used for yeast growth and genetic manipulations [42]. All strains used in this study are listed in Additional file 1: Table S1, and all plasmids used are listed in Additional file 1: Table S2. The plasmids were linearized by restriction enzymes and then used to transform yeast strains to make GFP tagged SEC3, $S E C 5, S E C 8$, and EXO70 on the chromosome, respectively. Yeast transformation was performed using lithium acetate method [11]. Briefly, about $2 \mathrm{OD}_{600}$ units of cells grown to early log phase were collected in a $1.5-\mathrm{ml}$ centrifuge tube and washed twice with $1 \mathrm{ml}$ of distilled water. To prepare the transformation reaction, $240 \mu \mathrm{l}$ PEG 3350 (50\% weight/volume), $36 \mu \mathrm{l} 1.0 \mathrm{M} \mathrm{LiAc,} 5 \mu \mathrm{l} 10 \mathrm{mg} / \mathrm{ml}$ ssDNA, and 0.1-10 $\mu \mathrm{g}$ DNA were added in order and the tube was vortexed until the cell pellet had been completely mixed. The suspended cells were incubated in a water bath pre-warmed to $42{ }^{\circ} \mathrm{C}$ for $30 \mathrm{~min}$. After that, $200 \mu \mathrm{l}$ of the transformation mix was plated onto a SDUra plate. The plates were incubated at $25^{\circ} \mathrm{C}$ for $3-4$ days to recover transformants.

\section{Bgl2 secretion}

The classical Bgl2 secretion assay was used in this study with minor modifications [14]. $20 \mathrm{ml}$ of yeast cells were grown to early log phase until $\mathrm{OD}_{600}$ is $0.6-1.0$ at $25^{\circ} \mathrm{C}$. $\mathrm{NaN}_{3}$ and $\mathrm{NaF}$ were added directly to the culture at a final concentration of $10 \mathrm{mM}$ each. $10 \mathrm{OD}_{600}$ units of cells were collected, washed with cell wash buffer $(20 \mathrm{mM}$ Tris- $\mathrm{HCl}, \mathrm{pH}$ 7.5, $10 \mathrm{mM} \mathrm{NaN}_{3}$, and $10 \mathrm{mM} \mathrm{NaF}$ ). The cells were resuspended in $300 \mu \mathrm{l}$ of spheroplast solution buffer (50 mM Tris-HCl, pH 7.5, 1.4 M sorbitol, $10 \mathrm{mM}$ $\mathrm{NaN}_{3}, 10 \mathrm{mM} \mathrm{NaF}, 30 \mathrm{mM}$ 2-Mercaptoethanol, and $0.2 \mathrm{mg} / \mathrm{ml} \mathrm{Zymolyase)}$ and incubated at $37{ }^{\circ} \mathrm{C}$ in a water bath for $30 \mathrm{~min}$. The spheroplasts were pelleted gently by centrifuge at $2000 \mathrm{rpm}$ for $5 \mathrm{~min}$ at $4{ }^{\circ} \mathrm{C}$. $100 \mu \mathrm{l}$ of supernatant was carefully transferred to a new tube and mixed with $20 \mu$ of $6 \times$ SDS loading buffer $(300 \mathrm{mM}$ Tris- $\mathrm{HCl}$, $\mathrm{pH}$ 6.8, $600 \mathrm{mM}$ dithiothreitol, 12\% SDS, 0.6\% bromophenol blue, and $60 \%$ glycerol). This is the external pool. The remaining supernatant was removed and the pellet (spheroplasts) was washed once with $1 \mathrm{ml}$ of spheroplast wash buffer $(50 \mathrm{mM}$ Tris- $\mathrm{HCl}, \mathrm{pH} 7.5,1.4 \mathrm{M}$ sorbitol,
$10 \mathrm{mM} \mathrm{NaN}_{3}$, and $10 \mathrm{mM} \mathrm{NaF}$ ) to remove residue external pool. The spheroplasts were dissolve in $300 \mu \mathrm{l}$ of lysate buffer (20 mM Tris- $\mathrm{HCl}, \mathrm{pH} 7.5,100 \mathrm{mM} \mathrm{NaCl}$, $2 \mathrm{mM} \mathrm{MgCl}_{2}, 0.5 \%$ Triton X-100, and $1 \times$ protease inhibitor cocktail from Roche Inc.) by leaving on ice for $10 \mathrm{~min}$. The cell debris was removed after the sample was centrifuged at 13,000 rpm for $5 \mathrm{~min}$ at $4{ }^{\circ} \mathrm{C} .100 \mu \mathrm{l}$ of supernatant (lysates) was transferred to a new tube and mixed with $20 \mu \mathrm{l}$ of $6 \times$ SDS loading buffer. This is the internal pool. The internal pool and external pool samples were boiled at $95^{\circ} \mathrm{C}$ for $5 \mathrm{~min}$, loaded into 12\% SDS-PAGE gel. $\mathrm{Bgl} 2$ was detected by Western blotting with an anti-Bgl2 rabbit polyclonal antibody (1:2,000 dilution). For temperature-sensitive mutants, the cells were grown at $25{ }^{\circ} \mathrm{C}$ or shifted to $39^{\circ} \mathrm{C}$ for $60 \mathrm{~min}$ before being processed for the Bgl2 assay. For myriocin treatment, the cells were exposed to $10 \mu \mathrm{g} / \mathrm{ml}$ myriocin for $60 \mathrm{~min}$ before being processed for secretion assays.

\section{Invertase secretion}

Invertase secretion was examined as described previously [35]. $20 \mathrm{ml}$ of yeast cells were grown to early log phase at $25{ }^{\circ} \mathrm{C}$ until $\mathrm{OD}_{600}$ is $0.6-1.0$. One $\mathrm{OD}_{600}$ cells were transferred to a new tube and washed with $1 \mathrm{ml}$ of ice cold $1 \mathrm{mM} \mathrm{NaN3}$. The cells were then resuspended in $1 \mathrm{ml}$ YP plus glucose medium (1\% Bacto-yeast, 2\% Bactopeptone, and $0.1 \%$ glucose) and incubated at $25{ }^{\circ} \mathrm{C}$ for $1 \mathrm{~h}$ to induce invertase expression. After $1 \mathrm{~h}$ of incubation, the cells were collected and washed once with $1 \mathrm{ml}$ $10 \mathrm{mM}$ NaN3. The cells were resuspended in $1 \mathrm{ml} 10 \mathrm{mM}$ $\mathrm{NaN} 3$ and kept on ice. The external invertase was measured directly on the whole intact cells, whereas the internal invertase was measured after preparation of lysates. $0.5 \mathrm{ml}$ of cells were removed and mixed with $0.5 \mathrm{ml}$ of $2 \times$ spheroplast cocktail mix $(2.8 \mathrm{M}$ sorbitol, $0.1 \mathrm{M}$ Tris- $\mathrm{HCl} \mathrm{pH} \mathrm{7.5,} 10 \mathrm{mM} \mathrm{NaN}_{3}, 0.4 \%$ 2-Mercaptoethanol, and $10 \mu \mathrm{g} / \mathrm{ml}$ Zymolyase-100 T). The cells were incubated in water bath at $37^{\circ} \mathrm{C}$ for $45 \mathrm{~min}$. The spheroplasts were collected and the supernatant was removed carefully without disturbing the pellet. The spheroplasts were dissolved at $4{ }^{\circ} \mathrm{C}$ in $0.5 \mathrm{ml} 0.5 \%$ Triton X-100. The invertase assay was performed in $13 \times 100 \mathrm{~mm}$ glass tubes. $20 \mu \mathrm{l}$ of sample was placed in the tube and $80 \mu \mathrm{l}$ of $50 \mathrm{mM} \mathrm{NaAc}, \mathrm{pH} 5.1$, was added. Then $25 \mu \mathrm{l}$ of $0.5 \mathrm{M}$ sucrose was added and the tube was incubated at $37^{\circ} \mathrm{C}$ for $30 \mathrm{~min} .150 \mu \mathrm{l}$ of $0.2 \mathrm{M} \mathrm{K}_{2} \mathrm{HPO}_{4}$ was added and the tube was placed on ice to stop the reaction. The sample was boiled for $3 \mathrm{~min}$ and put on ice. One $\mathrm{ml}$ of assay mix was added $(0.1 \mathrm{M} \mathrm{KP}$ buffer, $\mathrm{pH} 7.0,10 \mathrm{U} / \mathrm{ml}$ glucose oxidase, $2.5 \mu \mathrm{g} / \mathrm{ml}$ peroxidase, $150 \mu \mathrm{g} / \mathrm{ml} \mathrm{O}$-dianisidine, and $20 \mu \mathrm{M}$ N-Ethylmaleimide) and the sample was incubated at $37^{\circ} \mathrm{C}$ for $30 \mathrm{~min}$. One $\mathrm{ml}$ of $6 \mathrm{~N} \mathrm{HCl}$ was added into the tube and the value of $\mathrm{OD}_{540}$ was measured by the 
Spectrophotometer (SmartSpec 3000; Bio-Rad Laboratories). For temperature-sensitive mutants, the cells were grown at $25{ }^{\circ} \mathrm{C}$ or shifted to $39{ }^{\circ} \mathrm{C}$ for $60 \mathrm{~min}$ and then were grown in low-glucose medium $(0.1 \%$ glucose) at the same temperature for $1 \mathrm{~h}$. For cells treated with myriocin, the cells were treated with $10 \mu \mathrm{g} / \mathrm{ml}$ myriocin for $60 \mathrm{~min}$ before being processed for secretion assays.

\section{Fluorescent microscopy}

Chromosomal tagging of SEC3, SEC5, SEC8, and EXO70 with Green Fluorescence Protein (GFP) was performed as previously described [47]. Cells were grown to log phase at $25{ }^{\circ} \mathrm{C}$, then shifted to $39{ }^{\circ} \mathrm{C}$ or treated with myriocin for $60 \mathrm{~min}$. The cells were then fixed for microscopy as described previously [23]. Immuno-fluorescence staining of yeast cells was performed as previously described [26]. Rabbit anti-Sec4 was used at a 1:1,000 dilution followed by a secondary AlexaFluor594-conjugated goat anti-rabbit IgG antibody (Molecular Probes). Fluorescent microscopy was conducted with a fluorescence microscope (BX53; OLYMPUS) equipped with a Plan-Apochromat $\times 00,1.40 \mathrm{NA}$ oil immersion objective lens. Images were taken using cellSens Standard software (OLYMPUS). Images were processed using Adobe Photoshop CC 2019 software, and statistical analysis was performed using GraphPad Prism 7.0 software.

\section{Electron microscopy}

The electron microscopy (EM) was performed as the previous study with minor modifications [8]. Cells were collected by vacuum filtration using a $0.45 \mu \mathrm{m}$ nitrocellulose membrane and were fixed for $1 \mathrm{~h}$ at room temperature in $0.1 \mathrm{M}$ cacodylate, $\mathrm{pH} 7.4,3 \%$ formaldehyde, $1 \mathrm{mM} \mathrm{MgCl} 2$, and $1 \mathrm{mM} \mathrm{CaCl}_{2}$. The cells were spheroplasted and fixed with $1 \%$ glutaraldehyde (in PBS, $\mathrm{pH}$ 7.4) at $4{ }^{\circ} \mathrm{C}$ overnight. The spheroplasts were washed in $0.1 \mathrm{M}$ cacodylate buffer and were postfixed twice with ice-cold $0.5 \% \mathrm{OsO}_{4}$ and $0.8 \%$ potassium ferrocyanide for $10 \mathrm{~min}$ each. After dehydration and embedding in Spurr's epoxy resin (Polysciences, Inc.), thin sections were cut and transferred onto 600 mesh uncoated copper grids (Ernest Fullam, Inc.) and were post-stained with uranyl acetate and lead citrate. Cells were observed on a transmission electron microscope (Model 1010; JEOL) at $\times 100,000$ magnification.

\section{Statistical analysis}

Statistical analysis was performed using Graphpad Prism 7.0 software. One-way ANOVO was used for univariate analysis. $\mathrm{p}<0.05$ was considered statistically significant.

\section{Supplementary information}

Supplementary information accompanies this paper at https://doi. org/10.1186/s13578-020-00406-2.

Additional file 1: Figure S1. The amount of the GFP tagged exocyst subunits did not differ significantly change in Icb1-100 mutant and cells treated with myriocin. (A) The yeast strains harboring SEC3-GFP, SEC5-GFP, SEC8-GFP or EXO70-GFP on the chromosome were grown to early log phase in YPD liquid medium overnight at $25^{\circ} \mathrm{C}$. The cells were then shifted from $25^{\circ} \mathrm{C}$ to $39^{\circ} \mathrm{C}$ for $60 \mathrm{~min}$. Total protein was extracted and Western blots were performed using rabbit anti-GFP antiby (1:1000 dilution). Adh1 was used as a loading control (rabbit anti-Adh1 antibody). (B) Wild-type cells harboring SEC3-GFP, SEC5-GFP, SEC8-GFP or EXO70-GFP on the chromosome were grown to early log phase in YPD liquid medium overnight at $25^{\circ} \mathrm{C}$. The cells were then treated with or without $10 \mu \mathrm{g} / \mathrm{ml}$ myriocin for $60 \mathrm{~min}$. Total protein was extracted and Western blots were performed using rabbit anti-GFP antiby (1:1000 dilution). Adh1 was used as a loading control (rabbit anti-Adh1 antibody). Figure S2. Cell viability of wild type and Icb1-100 mutant cells at a restrictive temperature. (A) Icb1-100 mutant is temperature sensitive. Wild type and Icb1-100 mutant cells were grown to log phase in $Y P D$ at $25^{\circ} \mathrm{C}$, and equal densities of wildtype or Icb1-100 mutant cells were spotted in 10-fold serial dilutions from left to right on YPD plate, and then incubated at different temperatures for 3 days. (B) Viability of Icb1-100 mutant cells at restrictive temperature. Wild-type and Icb1-100 mutant cells were grown to early log phase in YPD liquid medium overnight at $25^{\circ} \mathrm{C}$ and then shift to $39^{\circ} \mathrm{C}$ for $60 \mathrm{~min}$. The cells were stained with $4 \%$ Loeffler's methylene blue solution for $10 \mathrm{~min}$ at room temperature. Cells were washed with PBS buffer and examined by microscopy. Cells stained with blue color are not viable. (C) Statistical analysis of cell viability in wild type and Icb1-100 mutant cells in (B). $n=3$. Three independent experiments were performed. ${ }^{*}, p<0.01$. Figure S3. Cell viability of wild type cells treated with or without myriocin. (A) Wild-type and Icb1-100 mutant cells were grown to early log phase in YPD liquid medium overnight at $25^{\circ} \mathrm{C}$. Myriocin was added into the medium to a final concentration of $10 \mu \mathrm{g} / \mathrm{ml}$, and the cells were incubated at $25^{\circ} \mathrm{C}$ for $60 \mathrm{~min}$. The cells were collected and stained with $4 \%$ Loeffler's methylene blue solution for $10 \mathrm{~min}$ at room temperature. Cells were washed with PBS buffer and examined by microscopy. Cells stained with blue color are not viable. (B) Statistical analysis of viability of wild type cells treated with myriocin in (A). $n=3$. Three independent experiments were performed. *, $p<0.01$. Table S1. Yeast strains used in this study. Table S2. Plasmids used in this study.

\section{Abbreviations}

EM: Electron microscopy; GFP: Green fluorescent protein; IPC: Inositolphosphoryl ceramide; LCB: Long-chain base; MIPC: Mannosyl-inositolphosphoryl ceramide; $M(I P)_{2} C$ : Mannosyl-diinositolphosphoryl ceramide; SNARE: Soluble $\mathrm{N}$-ethylmaleimide-sensitive factor activating protein receptor; SONC: Saturated overnight culture; SPT: Serine palmitoyl-transferase; TGN: Trans-Golgi network; WT:Wild type; Ve: Vesicle.

\section{Acknowledgements}

We thank Drs. Difei Wang and Shengnan Meng for their help and knowledge of the experimental design and methods.

\section{Authors' contributions}

QG, GL, and YL designed research; QG, TZ, YD, YM, and DS performed research; $\mathrm{QG}, T Z, Y L$, and $G L$ analyzed data; and QG, TZ, YL, and GL wrote the paper. The authors declare no conflict of interest. All authors read and approved the final manuscript.

\section{Funding}

This work is supported by the National Natural Science Foundation of China (No. 31570819).

\section{Availability of data and materials}

The data and materials used and/or analyzed during the current study are available from the corresponding author on reasonable request. 
Ethics approval and consent to participate

Not applicable.

\section{Consent for publication}

Not applicable.

\section{Competing interests.}

The authors declare that they have no competing interests.

Received: 5 January 2020 Accepted: 10 March 2020

Published online: 30 March 2020

\section{References}

1. Boyd C, Hughes T, Pypaert M, Novick P. Vesicles carry most exocyst subunits to exocytic sites marked by the remaining two subunits, Sec3p and Exo70p. J Cell Biol. 2004;167:889-901.

2. Buede R, Rinker-Schaffer C, Pinto WJ, Lester RL, Dickson RC. Cloning and characterization of LCB1, a Saccharomyces gene required for biosynthesis of the long-chain base component of sphingolipids. J Bacteriol. 1991;173:4325-32.

3. Clarke J, Dephoure N, Horecka I, Gygi S, Kellogg D. A conserved signaling network monitors delivery of sphingolipids to the plasma membrane in budding yeast. Mol Biol Cell. 2017;28:2589-99.

4. Cowart LA, Okamoto Y, Lu X, Hannun YA. Distinct roles for de novo versus hydrolytic pathways of sphingolipid biosynthesis in Saccharomyces cerevisiae. Biochem J. 2006:393:733-40.

5. Daquinag A, Fadri M, Jung SY, Qin J, Kunz J. The yeast PH domain proteins $\operatorname{SIm} 1$ and SIm 2 are targets of sphingolipid signaling during the response to heat stress. Mol Cell Biol. 2007:27:633-50.

6. Dickson RC, Sumanasekera C, Lester RL. Functions and metabolism of sphingolipids in Saccharomyces cerevisiae. Prog Lipid Res. 2006:45:447-65.

7. Dickson RC, Lester RL. Sphingolipid functions in Saccharomyces cerevisiae. Biochim Biophys Acta. 2002;1583:13-25.

8. Duan Y, Guo Q, Zhang T, Meng Y, Sun D, Luo G, Liu Y. Cyclin-dependent kinase-mediated phosphorylation of the exocyst subunit Exo84 in late G1 phase suppresses exocytic secretion and cell growth in yeast. J Biol Chem. 2019;294:11323-32.

9. Evangelista M, Pruyne D, Amberg DC, Boone C, Bretscher A. Formins direct Arp2/3-independent actin filament assembly to polarize cell growth in yeast. Nat Cell Biol. 2002;3:260-9.

10. Finger FP, Hughes TE, Novick P. Sec3p is a spatial landmark for polarized secretion in budding yeast. Cell. 1998:92:559-71.

11. Gietz D, Jean A, Woods RA, Schiestl RH. Improved method for high efficiency transformation of intact yeast cells. Nucleic Acids Res. 1992;20:1425.

12. Guo W, Sacher M, Barrowman J, Ferro-Novick S, Novick P. Protein complexes in transport vesicle targeting. Trends Cell Biol. 2000;10:251-5.

13. Guo W, Tamanoi F, Novick P. Spatial regulation of the exocyst complex by Rho1 GTPase. Nat Cell Biol. 2001;3:353-60.

14. Harsay E, Bretscher A. Parallel secretory pathways to the cell surface in yeast. J Cell Biol. 1995;131:297-310.

15. He B, Guo W. The exocyst complex in polarized exocytosis. Curr Opin Cell Biol. 2009;21:537-42.

16. He B, Xi F, Zhang X, Zhang J, Guo W. Exo70 interacts with phospholipids and mediates the targeting of the exocyst to the plasma membrane. EMBO J. 2007:26:4053-65.

17. Hearn JD, Lester RL, Dickson RC. The uracil transporter Fur4p associates with lipid rafts. J Biol Chem. 2003;278:3679-86.

18. Hsu SC, TerBush D, Abraham M, Guo W. The exocyst complex in polarized exocytosis. Int Rev Cytol. 2004;233:243-65.

19. Jenkins GM, Hannun YA. Role for de novo sphingoid base biosynthesis in the heat-induced transient cell cycle arrest of Saccharomyces cerevisiae. J Biol Chem. 2001;11:8574-81.

20. Klemm RW, Ejsing CS, Surma MA, Kaiser HJ, Gerl MJ, Sampaio JL, de Robillard Q, Ferguson C, Proszynski TJ, Shevchenko A, Simons K. Segregation of sphingolipids and sterols during formation of secretory vesicles at the trans-Golgi network. J Cell Biol. 2009:185:601-12.

21. Lee MC, Hamamoto S, Schekman R. Ceramide biosynthesis is required for the formation of the oligomeric $\mathrm{H}+$-ATPase Pma1 $\mathrm{p}$ in the yeast endoplasmic reticulum. J Biol Chem. 2002;277:22395-401.
22. Liu J, Huang X, Withers BR, Blalock E, Liu K, Dickson RC. Reducing sphingolipid synthesis orchestrates global changes to extend yeast lifespan. Aging Cell. 2013;12:833-41.

23. Liu Y, Zhang T, Sun D, Luo G. The Cdc42 effectors Gic1 and Gic2 regulate polarized post-Golgi secretion. Cell Biosci. 2019;9:33.

24. Liu K, Zhang X, Lester RL, Dickson RC. The sphingoid long chain base phytosphingosine activates AGC-type protein kinases in Saccharomyces cerevisiae including Ypk1, Ypk2, and Sch9. J Biol Chem. 2005:280:22679-87.

25. Luo G, Zhang J, Luca FC, Guo W. Mitotic phosphorylation of Exo84 disrupts exocyst assembly and arrests cell growth. J Cell Biol. 2013;202:97-111.

26. Luo G, Zhang J, Guo W. The role of Sec3p in secretory vesicle targeting and exocyst complex assembly. Mol Biol Cell. 2014;25:3813-22.

27. Luo G, Gruhler A, Liu Y, Jensen ON, Dickson RC. The sphingolipid long-chain base-Pkh1/2-Ypk1/2 signaling pathway regulates eisosome assembly and turnover. J Biol Chem. 2008;283:10433-44.

28. McCusker D, Denison C, Anderson S, et al. Cdk1 coordinates cell-surface growth with the cell cycle. Nat Cell Biol. 2007;9:506-15.

29. McCusker D, Royou A, Velours C, Kellogg D. Cdk1-dependent control of membrane-trafficking dynamics. Mol Biol Cell. 2012;23:3336-47.

30. Meier KD, Deloche O, Kajiwara K, Funato K, Riezman H. Sphingoid base is required for translation initiation during heat stress in Saccharomyces cerevisiae. Mol Biol Cell. 2006;17:1164-75.

31. Montefusco DJ, Matmati N, Hannun YA. The yeast sphingolipid signaling landscape. Chem Phys Lipids. 2014;177:26-40.

32. Mora A, Komander D, van Aalten DM, Alessi DR. PDK1, the master regulator of AGC kinase signal transduction. Semin Cell Dev Biol. 2004;15:161-70.

33. Munson M, Novick P. The exocyst defrocked, a framework of rods revealed. Nat Struct Mol Biol. 2006;13:577-81.

34. Novick P, Ferro S, Schekman R. Order of events in the yeast secretory pathway. Cell. 1981:25:461-9.

35. Novick P, Field C, Schekman R. Identification of 23 complementation groups required for post-translational events in the yeast secretory pathway. Cell. 1980;21:205-15.

36. Ogretmen B. Sphingolipid metabolism in cancer signalling and therapy. Nat Rev Cancer. 2018:18:33-50.

37. Proszynski TJ, Klemm RW, Gravert M, Hsu PP, Gloor Y, Wagner J, Kozak K, Grabner H, Walzer K, Bagnat M, Simons K, Walch-Solimena C. A genomewide visual screen reveals a role for sphingolipids and ergosterol in cell surface delivery in yeast. Proc Natl Acad Sci U S A. 2005;102:17981-6.

38. Reck-Peterson SL, Novick PJ, Mooseker MS. The tail of a yeast class $\checkmark$ myosin, myo2p, functions as a localization domain. Mol Biol Cell. 1999:4:1001-177

39. Roumanie O, Wu H, Molk JN, Rossi G, Bloom K, Brennwald P. Rho GTPase regulation of exocytosis in yeast is independent of GTP hydrolysis and polarization of the exocyst complex. J Cell Biol. 2005;4:583-94.

40. Schekman R, Novick P. 23 genes, 23 years later. Cell. 2004;116:S13-S1515.

41. Sheu YJ, Barral Y, Snyder M. Polarized growth controls cell shape and bipolar bud site selection in Saccharomyces cerevisiae. Mol Cell Biol. 2000;14:5235-47.

42. Sherman F. Getting started with yeast. Methods Enzymol. 2002;350:3-41.

43. Surma MA, Klose C, Klemm RW, Ejsing CS, Simons K. Generic sorting of raft lipids into secretory vesicles in yeast. Traffic. 2011;12:1139-47.

44. Whyte JRC, Munro S. Vesicle tethering complexes in membrane traffic. J Cell Sci. 2002:115:2627-37.

45. Wu B, Guo W. The exocyst at a glance. J Cell Sci. 2015;128:2957-64.

46. Zanolari B, Friant S, Funato K, Sütterlin C, Stevenson BJ, Riezman H. Sphingoid base synthesis requirement for endocytosis in Saccharomyces cerevisiae. EMBO J. 2000;19:2824-33.

47. Zhang T, Sun D, Luo G, Liu Y. Spatial and translational regulation of exocyst subunits by cell cycle in budding yeast. Med Sci Monit. 2019:25:4059-67.

48. Zhang $X$, Orlando K, He B, et al. Membrane association and functional regulation of Sec3 by phospholipids and Cdc42. J Cell Biol. 2008;180:145-58.

49. Zhang $X, B i E$, Novick $P$, et al. Cdc42 interacts with the exocyst and regulates polarized secretion. J Biol Chem. 2001:276:46745-50.

\section{Publisher's Note}

Springer Nature remains neutral with regard to jurisdictional claims in published maps and institutional affiliations. 